\title{
Different packages in the post-harvest quality of strawberry (cv. Camarosa)
}

\section{Carolina Carvalho Rocha Sena', Yanuzi Mara Vargas Camilo², Zeuxis Rosa Evangelista', Kari Katiele Souza Araujo ${ }^{3}$, Leandra Regina Semensato ${ }^{4}$}

\author{
${ }^{1}$ Universidade Federal de Goiás, Campus Samambaia, Goiânia, Goiás, Brasil. E-mail: eng.carolinasena@ gmail.com, \\ zeuxisrosa@hotmail.com \\ ${ }^{2}$ Centro Universitário de Anápolis, UniEvangélica, Anápolis, Goiás, Brasil. E-mail: yanuzimvc@gmail.com \\ ${ }^{3}$ Universidade Estadual de Goiás, Campus Anápolis de Ciência Exatas e Tecnológicas - Henrique Santillo, Anápolis, Goiás, Brasil. \\ E-mail: kari.katiele@gmail.com \\ ${ }^{4}$ Centro Universitário de Goiás, Uni-Anhanguera, Goiânia, Goiás, Brasil. E-mail: ledocepe@ gmail.com
}

Received: 15/01/2019; Accepted: 29/07/2019.

\section{ABSTRACT}

The method and temperature of storage of a product are the basic agents that make it possible to prolong the postharvest life of strawberries. In this context, this study aimed to evaluate the use of different packages with the passive modified atmosphere in the post-harvest quality of strawberry (cv. Camarosa). The strawberries were harvested and subsequently transported to the Laboratory of Drying and Post-harvest Storage of Agricultural Products, where they were stored in $\mathrm{BOD}$, at $0^{\circ} \mathrm{C}$, and $90 \pm 5 \%$ relative air humidity. A completely randomized design was used, in a $3 \times 5$ factorial scheme (three packages: expanded polystyrene (EPS) packaging + polyvinyl chloride (PVC) film at $0{ }^{\circ} \mathrm{C}$; polyethylene terephthalate (PET) packaging at $0{ }^{\circ} \mathrm{C}$; and without packaging at $0{ }^{\circ} \mathrm{C}$ (control) $\mathrm{x}$ five analysis: at $0,2,4,6$, and 8 days of storage), with four replications per day for each treatment. Averages were compared by Tukey test at $5 \%$ probability. The variables, fresh mass loss, pulp firmness, pH, soluble solids (SS), titratable acidity (TA) and SS/TA ratio were analyzed. The tested packages had better results when compared to the control treatment. The use of polyethylene terephthalate (PET) packages at $0^{\circ} \mathrm{C}$ had a less fresh mass loss during storage days, lower acidity reduction, and no significant decrease in pulp firmness.

Keywords: Storage, modified atmosphere, Fragaria $x$ ananassa.

\section{Diferentes embalagens na qualidade pós-colheita do morango (cv. Camarosa)}

\section{RESUMO}

A forma e a temperatura de armazenamento de um produto são os agentes básicos que possibilitam prolongar a vida pós-colheita do morango. Nesse contexto, o objetivo deste trabalho foi avaliar o uso de diferentes embalagens com atmosfera modificada passiva na qualidade pós-colheita do morango (cv. Camarosa). Os morangos foram colhidos e posteriormente transportados para o Laboratório de Secagem e Armazenamento Pós-Colheita de Produtos Agrícolas, onde ficaram armazenados em BOD a $0^{\circ} \mathrm{C}$ e umidade relativa do ar de $90 \pm 5 \%$. Foi utilizado o delineamento inteiramente casualizado, em esquema fatorial 3 x 5 (três embalagens: embalagem de poliestireno expandido (EPS) + filme de cloreto de polivinila (PVC); polietileno tereftalato (PET); e sem embalagem (controle) $\mathrm{x}$ cinco dias de análise: $0,2,4,6,8$ ), com quatro repetições por dia de análise para cada tratamento. As médias foram comparadas pelo teste de Tukey, a $5 \%$ de probabilidade. As variáveis analisadas foram: perda de massa, firmeza, $\mathrm{pH}$, sólidos solúveis, acidez titulável e relação sólidos solúveis e acidez titulável (SS/AT). As embalagens testadas apresentaram melhores resultados quando comparadas com o tratamento controle. $\mathrm{O}$ uso de embalagens de polietileno tereftalato (PET) a $0^{\circ} \mathrm{C}$ apresentou menor perda de massa ao longo dos dias de armazenamento, menor revolução da acidez e não ocorreu diminuição significativa na firmeza.

Palavras-chave: Armazenamento, atmosfera modificada, Fragaria x ananassa. 


\section{Introduction}

Strawberry (Fragaria $x$ ananassa) is admired worldwide, being the species with the highest economic expression among small red fruits. With intense red color, firm pulp, conical shape, strawberry is rich in vitamins C, B1, B2, B5, minerals and phenolic compounds, and it is indicated in cases of diet, as $100 \mathrm{~g}$ of fruits has only 39 calories (Cajamarca et al., 2017; Giampieri et al., 2012).

The adaptability of different strawberry cultivars allows their cultivation in different Brazilian states, which directly reflects on yield, quality, storage period, and response to applied post-harvest treatments (Chitarra and Chitarra, 2005). Consumers prefer fresh strawberry; however, its high post-harvest perishability due to its intense metabolic activity after the harvest makes it susceptible to attack by rot-causing pathogens, limiting its shelf life and commercialization in new markets (Araque et al., 2018).

The use of low temperatures is an essential tool for prolonging the post-harvest life of strawberries due to its effect on metabolic reaction rates (Flores Cantillano et al., 2008), interfering with vital processes such as respiration, ripening, loss of mass and pulp firmness (Chitarra and Chitarra, 2005). However, for prolonged storage, cooling alone is not enough for maintenance and fruit quality, and other techniques need to be employed to extend fruit shelf life (Chen et al., 2016).

Relative air humidity also affects product quality: if it is too low, it produces dehydration of the vegetable, and if it is too high the problems with rot increase. In most fruits and vegetables, high humidity is recommended, around 85 - 95\% (Flores Cantillano et al., 2008). For Cunha Junior et al. (2012), the ideal temperature for strawberry post-harvest conservation is from 0 to $1{ }^{\circ} \mathrm{C}$, relative air humidity from 90 to $95 \%$, and storage for seven days.

The use of a modified atmosphere, associated with the cooling effect, avoids or slows down the metabolic processes involved in the action of degradative and oxidative enzymes, and reduces respiration and ethylene production (Chitarra and Chitarra, 2005). Modified atmosphere is the presence of an artificial barrier - such as plastic film packing - to the diffusion of gases around the product, which results in reduced $\mathrm{O}_{2}$ level, increased $\mathrm{CO}_{2}$ level, change in ethylene concentration and water vapor, and changes in other volatile compounds (Cunha Junior et al., 2012).

According to Santos and Oliveira (2012), the use of the modified atmosphere is for the preservation of fruit and vegetable quality, as it contributes to the reduction of metabolic activity and water loss, which improves the commercial aspect and reflects the increase product shelf life during commercialization. Thus, the choice of suitable packaging for the conservation of strawberries requires the knowledge of several temperaturedependent variables, since its elevation promotes an increase in the respiratory rate of the products and the permeability of the film used (Araque et al., 2018).

In this context, this study aimed to evaluate the use of different packages with the passive modified atmosphere and refrigeration on the post-harvest quality of strawberry (cv. Camarosa).

\section{Material and Methods}

For the research, strawberries (cv. Camarosa) produced in a farm located in Goianápolis, GO were used. After harvest, fruits were visually selected for size, color, and absence of defects. Subsequently, the fruits were transported to the Laboratory of Drying and Post-harvest Storage of Agricultural Products, of the Campus of Exact and Technological Sciences, of the Goiás State University, in Anápolis - GO.

The treatments studied were: expanded polystyrene (EPS) packaging + polyvinyl chloride (PVC) film at 0 ${ }^{\circ} \mathrm{C}$; polyethylene terephthalate (PET) packaging at $0{ }^{\circ} \mathrm{C}$; and without packaging at $0{ }^{\circ} \mathrm{C}$. Strawberries were wrapped in the packages under refrigerated storage conditions; on the same day, that experiment was set up, and they were kept in a climate-controlled incubator (BOD) at $85-90 \%$ relative air humidity and $0{ }^{\circ} \mathrm{C}$.

The quality of strawberries were analyzed about: a) fresh mass loss: obtained by the difference in mass between the harvest day and the day of analysis; b) pulp firmness: using Brookfield CT3 50K texture analyzer; c) $\mathrm{pH}$ : determined by potentiometry using a DMPH-2 Digimed $\mathrm{pH}$ meter; d) titratable acidity: determined by titration with solution of $0.1 \mathrm{~mol} \mathrm{~L}^{-1} \mathrm{NaOH}$, with the result expressed as g citric acid $100 \mathrm{~g}^{-1}$ pulp; e) SS/TA ratio: determined by the relationship between soluble solids content and titratable acidity (IAL, 2005).

The analysis was performed every two days $(0,2,4$, 6,8 days). A completely randomized statistical design was used, with a $3 \times 5$ factorial scheme (packages $\mathrm{x}$ days of storage), with four replications per day of analysis for each treatment. Data from fruit analyzes were submitted to the analysis of variance $(p<0.05)$. After finding the significance, the means were compared by Tukey test at $5 \%$ probability. For statistical analysis, the SISVAR 5.3 software was used (Ferreira, 2014).

\section{Results and Discussion}

For the variables, fresh mass loss, $\mathrm{pH}$, soluble solids, and titratable acidity, there was a significant interaction between the types of packaging and storage day. For the pulp firmness variable, there was no significant influence of any factor analyzed. 
The fresh mass loss had statistical difference both for the treatments with different packages and the storage days (Figure 1), a fact verified by Cajamarca et al. (2017), who, when working with strawberry, observed statistical difference due to the interaction between treatment and storage period for the percentage of fresh mass loss. Mass loss leads to a faster cell membrane disintegration rate, resulting in wilting and loss of juiciness in strawberries (Flores Cantillano et al., 2008).

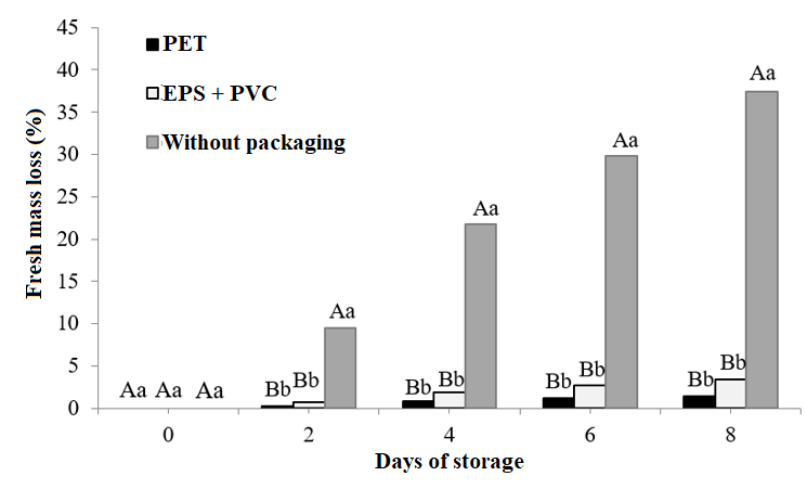

Figure 1. Average values of fresh mass loss (\%) of strawberries (cv. Camarosa) stored in different packages with the passive modified atmosphere at $0{ }^{\circ} \mathrm{C}$. EPS - Expanded Polystyrene Packaging; PVC - Polyvinyl Chloride Film; PET Polyethylene Terephthalate; Without packaging (control).

The highest average fresh mass loss was observed in the control treatment (without packaging), which differ statistically from the other treatments, which, in turn, did not differ from each other. However, the storage treatment of strawberry in EPS + PVC packaging had higher fresh mass loss than PET packaging. The average fresh mass loss increased for all treatments with storage. Flores Cantillano et al. (2008) also observed that the fresh mass loss increased with the extension of the storage period of strawberries.

According to García et al. (1998), the maximum commercially tolerated fresh mass loss for strawberries is $6 \%$. For the analyzed treatments, EPS + PVC and PET had the maximum fresh mass loss of $3.22 \%$ and $1.43 \%$, simultaneously, which is within the stipulated limits for commercialization, and storage without packaging had a fresh mass loss of $37.47 \%$ after eight days storage at $0{ }^{\circ} \mathrm{C}$. Yamashita et al. (2006), when working with the packaging on strawberries, observed that unpackaged strawberries lost $15 \%$ of initial fresh mass after ten days of storage at $12{ }^{\circ} \mathrm{C}$, thus presenting the highest averages of fresh mass loss.

The marked loss in unpackaged treatment is due to the high respiration and perspiration activity of the fruit, which occurs shortly after harvest. According to Oliveira et al. (2015), the packages are barriers to the movement of water vapor, favoring the maintenance of the high relative air humidity and turgor of the products, reducing the water loss in the form of vapor to the environment. Therefore, treatments using packaging had effects on the post-harvest life of strawberry (cv. Camarosa).

Regarding the pulp firmness attribute, during the days of storage and regarding the different types of packaging, there was no statistical difference (Table 1), fact also observed by Flores Cantillano et al. (2008) on strawberry storage. The change in pulp firmness is a natural consequence of the senescence process and also of the atmosphere in which the fruit is stored (Cordenunsi et al., 2003), and its maintenance throughout the post-harvest management of the strawberry is correlated with the best conditions of the fruit conservation (Brackmann et al., 2011).

It was observed that on harvest day, the average pulp firmness of the fruit was $5.25 \mathrm{~N}$, and on the last day of storage (eighth storage day) was $6.37,6.50$, and $6.12 \mathrm{~N}$ for the storage in EPS + PVC, PET and without packaging, respectively. There was an increase between the day of harvest and the end of storage for the different packaging, without significant difference. An increment was also observed by Bender et al. (2010) on pulp firmness values, which attributed this behavior as a result of dehydration. Variations in fruit firmness can be explained by the formation of soluble pectin due to partial hydrolysis of the insoluble cell wall constituent protopectin (Flores Cantillano et al., 2008), as it affects shelf life, since fruits of reduced pulp firmness have less resistance to damage from transportation and packaging (Bieniasz et al., 2012).

Regarding the $\mathrm{pH}$ variable, a statistical difference was obtained due to the interaction between treatment and storage period ( $\mathrm{p}<0.05$ ), as observed by Cajamarca et al. (2017) in the strawberry. The $\mathrm{pH}$ ranged from 3.83 to 4.30 (Table 1), values close to those reported by Guimarães et al. (2014), where strawberry $\mathrm{pH}$ increased from 3.42 to 3.81 during storage.

The average $\mathrm{pH}$ values of strawberry (cv. Camarosa) had significant differences for the different types of packaging with the passive modified atmosphere; It was only on the second storage day that the treatment without packaging differed statistically $(\mathrm{p}<0.05)$ from PET packaging, with an average of 4.06, and EPS + PVC, with an average of 3.93. The results of Soares et al. (2011) corroborate since when evaluating the maintenance of the postharvest quality of strawberries packaged in different packages, they also had no significant influence on the average $\mathrm{pH}$ values.

The influence of PET packaging resulted in the highest $\mathrm{pH}$ averages concerning storage days when compared to treatments with packaging, with values ranging from 3.83 on harvest day to 4.06 on the second storage day. Treatment without packaging had the highest average $\mathrm{pH}$ on the second storage day, with a value of 4.30. Flores Cantillano et al. (2008) observed a 
significant difference only in the evaluation made on the ninth day, which presented the lowest $\mathrm{pH}$ value.

The treatments with PET packaging and without packaging had a significant difference concerning the storage day. On harvest day and the second storage day, there was an increase in $\mathrm{pH}$ values. With these values, it can be said that the $\mathrm{pH}$ behavior is not influenced using different packages since the treatment without packaging had similar behavior to the others.

Soluble solids varied significantly between packaging and storage time at $5 \%$ probability (Table 1). Panda et al. (2016) observed that soluble solids of strawberry fruits packaged in different packaging materials had significant variation concerning the storage period, but variation concerning the type of packaging films used was not observed.

The average values of soluble solids remained in the range between 5.37 (EPS + PVC, on the fourth storage day) and $8.87^{\circ}$ Brix (without packaging, on the sixth storage day) throughout storage for the different packages. These values corroborate those found by Cajamarca et al. (2017), which were in the range between 6.80 and $7.80{ }^{\circ}$ Brix.

It can be noted that the treatment without packaging had the highest values of soluble solids, both concerning the other packages and concerning the days of analysis (Table 1). Only on the fourth and sixth storage day, there was a significant difference in EPS + PVC and PET packaging compared to treatment without packaging.

Treatments using PET packaging and without packaging had an increase in soluble solids content during strawberry storage, increasing from 6.50 to 7.15 ${ }^{\circ}$ Brix and from 6.50 to $7.60^{\circ}$ Brix, respectively. Chitarra and Chitarra (2005) report that soluble solids content tends to increase with maturation, mainly consisting of sugars.

EPS + PVC packaging did not differ statistically ( $p$ $<0.05$ ) in the concentration of soluble solids during storage, evidencing that this packaging does not influence this parameter in strawberry post-harvest. However, in this treatment, the soluble solids behaved decreasingly during storage. Decreasing behavior was observed by Andrade Júnior et al. (2016), who reported a decrease in soluble solids content in strawberries stored in a cold chamber over time. The same authors justify this behavior by the fact that fruits use sugars as a source of energy to maintain metabolic activity, such as respiration.

From an industrial point of view, a lower $\mathrm{pH}$ (less than 3.5) is preferable due to the inhibition of bacterial growth (Macedo and Alvarenga, 2005). However, fruits that are not as acidic are desirable for fresh consumption. In no analysis was obtained average $\mathrm{pH}$ values lower than 3.5, evidencing that about this characteristic, the fruits were suitable for commercialization.

All treatments had a decrease in the titratable acidity values between harvest and the last storage day (eighth storage day). However, between harvest day and the second storage day, there was a significant difference in the values for all treatments, and after that date, the titratable acidity had an increase, however, not up to its initial value.

Table 1. Averages values of pulp firmness (N), pH, soluble solids ( ${ }^{\circ}$ Brix), titratable acidity ( $\mathrm{g}$ acid $100 \mathrm{~g}^{-1}$ of pulp), and SS/TA ratio of strawberry (cv. Camarosa) stored in different packages with the passive modified atmosphere.

\begin{tabular}{|c|c|c|c|c|c|}
\hline \multirow{2}{*}{ Packaging } & \multicolumn{5}{|c|}{ Days } \\
\hline & 0 & 2 & 4 & 6 & 8 \\
\hline \multicolumn{6}{|c|}{ Pulp firmness $(\mathrm{N})$} \\
\hline EPS + PVC & $5.25 \mathrm{Aa}$ & $6.87 \mathrm{Aa}$ & $8.25 \mathrm{Aa}$ & $7.37 \mathrm{Aa}$ & $6.37 \mathrm{Aa}$ \\
\hline PET & $5.25 \mathrm{Aa}$ & $7.12 \mathrm{Aa}$ & $6.62 \mathrm{Aa}$ & $7.12 \mathrm{Aa}$ & $6.50 \mathrm{Aa}$ \\
\hline Without packaging & $5.25 \mathrm{Aa}$ & $8.00 \mathrm{Aa}$ & 5.12Aa & $5.75 \mathrm{Aa}$ & $6.12 \mathrm{Aa}$ \\
\hline \multicolumn{6}{|c|}{$\mathrm{pH}$} \\
\hline EPS + PVC & $3.83 \mathrm{Aa}$ & $3.93 \mathrm{Ab}$ & 3.84Aa & $4.01 \mathrm{Aa}$ & 3.91Aa \\
\hline PET & $3.83 \mathrm{Ba}$ & $4.06 \mathrm{Ab}$ & $4.00 \mathrm{ABa}$ & $4.02 \mathrm{ABa}$ & $4.00 \mathrm{ABa}$ \\
\hline Without packaging & $3.83 \mathrm{Ba}$ & $4.30 \mathrm{Aa}$ & $3.97 \mathrm{Ba}$ & $4.00 \mathrm{Ba}$ & $3.95 \mathrm{Ba}$ \\
\hline \multicolumn{6}{|c|}{ Soluble solids ( ${ }^{\circ}$ Brix) } \\
\hline EPS + PVC & $6.50 \mathrm{ABa}$ & $7.05 \mathrm{Aa}$ & $5.37 \mathrm{Bb}$ & $6.80 \mathrm{ABb}$ & $6.30 \mathrm{ABa}$ \\
\hline PET & $6.50 \mathrm{Aa}$ & $6.57 \mathrm{Aa}$ & $6.45 \mathrm{Ab}$ & $6.45 \mathrm{Ab}$ & $7.15 \mathrm{Aa}$ \\
\hline Without packaging & $6.50 \mathrm{Ba}$ & $7.10 \mathrm{Ba}$ & 8.07Aa & 8.87Aa & $7.60 \mathrm{ABa}$ \\
\hline \multicolumn{6}{|c|}{ Titratable acidity (g acid $100 \mathrm{~g}^{-1}$ of pulp) } \\
\hline EPS + PVC & $1.23 \mathrm{Aa}$ & $0.78 \mathrm{Ba}$ & $1.18 \mathrm{Aa}$ & $0.91 \mathrm{ABa}$ & $1.08 \mathrm{ABa}$ \\
\hline PET & $1.23 \mathrm{Aa}$ & $0.86 \mathrm{Ba}$ & $0.81 \mathrm{Bb}$ & $0.86 \mathrm{Ba}$ & $1.11 \mathrm{ABa}$ \\
\hline Without packaging & $1.23 \mathrm{Aa}$ & $0.78 \mathrm{Ba}$ & $0.99 \mathrm{ABab}$ & $1.14 \mathrm{Ba}$ & $1.13 \mathrm{Ba}$ \\
\hline \multicolumn{6}{|c|}{ SS/TA ratio } \\
\hline EPS + PVC & $5.32 \mathrm{Ba}$ & $9.24 \mathrm{Aa}$ & $4.78 \mathrm{Bb}$ & 7.69ABa & $5.84 \mathrm{Ba}$ \\
\hline PET & $5.32 \mathrm{Aa}$ & 7.74Aab & $8.23 \mathrm{Aa}$ & $7.55 \mathrm{Aa}$ & $6.45 \mathrm{Aa}$ \\
\hline Without packaging & $5.32 \mathrm{Aa}$ & $5.59 \mathrm{Ab}$ & $8.12 \mathrm{Aa}$ & $7.93 \mathrm{Aa}$ & $7.54 \mathrm{Aa}$ \\
\hline
\end{tabular}

Averages followed by the same letter, lowercase in the column, and uppercase in the row do not differ from each other by the Tukey test (p <5\%). EPS - Expanded Polystyrene Packaging; PVC - Polyvinyl Chloride Film; PET - Polyethylene Terephthalate. 
Titratable acidity generally decreased between harvest and storage, a fact also observed by Flores Cantillano et al. (2008). Bender et al. (2010) did not observe decreases in titratable acidity during the storage of strawberries, but they were not significant. Acidity, due to the presence of organic acids, it is an essential attribute concerning the taste and aroma of many fruits (Castricini et al., 2017).

Acidity has no significant difference due to the respiratory process; fruit acidity tends to decrease in ripening due to acid degradation (Chitarra and Chitarra, 2005). Other works with strawberry storage also prove the tendency to change titratable acidity (Castricini et al., 2017; Andrade Júnior et al., 2016).

For the titratable acidity variable, only on the fourth day of storage, there was a significant difference $(\mathrm{p}<0.05)$ between EPS + PVC and PET packaging, and the control treatment did not differ from PET packaging. Soares et al. (2011) found that for titratable acidity values, there was no significant influence on the type of packaging or storage time. The oscillation in titratable acidity during storage may be related to the biochemical processes of respiratory metabolism, which both synthesizes and consumes organic acids (Oliveira et al., 2014), besides the genetic variability of the fruits analyzed.

The SS/TA ratio indicates the existence of an equilibrium between these two components, specifying the minimum solids content and the maximum acidity to determine the real flavor with higher precision (Cordenunsi et al., 2003). Table 1 shows that there was an increase in SS/TA ratio from harvest day to the second storage day, differing statistically for EPS + PVC packaging during storage. There was a nonsignificant increase in SS/AT ratio from the start to the end date of storage. Flores Cantillano et al. (2008) noted an increase in the SS/TA ratio between harvest and storage for the analyzed strawberries.

The different packages analyzed had significant difference only on the fourth storage day, where EPS + PVC treatment differed from control treatment, and PET treatment was more efficient in maintaining the SS/TA ratio. Andrade Júnior et al. (2016) noted a significant effect of strawberry storage on the SS/TA ratio.

SS/TA ratio during storage ranged from 5.32 for the harvest day to 7.6 for the sixth storage day. When this ratio is low, the product is tasteless and loses quality (Andrade Júnior et al., 2016). Thus, fruits stored until the sixth day are likely to be well accepted by the consumer.

\section{Conclusions}

The use of polyethylene terephthalate (PET) packaging at $0{ }^{\circ} \mathrm{C}$ presents favorable results under the conditions established for the maintenance of strawberry (cv. Camarosa), showing lower fresh mass loss during storage days $(1.43 \%)$, lower titratable acidity instability (ranging from 0.81 to $1.23 \mathrm{~g}$ acid $100 \mathrm{~g}^{-1}$ of pulp) and $\mathrm{pH}$ ranging from 3.83 to 4.06 ; and without significant decrease in pulp firmness during the eight days of storage.

\section{Bibliographic References}

Andrade Júnior, V.C., Guimarães, A.G., Azevedo, A.M., Pinto, N.A.V.D., Ferreira, M.A.M., 2016. Conservação póscolheita de frutos de morangueiro em diferentes condições de armazenamento. Horticultura Brasileira, 34(3), 405-411.

Araque, L.C.O., Rodoni, L.M., Darré, M., Ortiz, C.M., Civello P.M., Vicente, A.R., 2018. Cyclic low dose UV-C treatments retain strawberry fruit quality more effectively than conventional pre-storage single high fluence applications. Food Science and Technology, 92, 304-311.

Bender, R.J., Pezzi, E., Leão, M.L., Casali, M.E., 2010. Armazenagem de morangos cv. Camarosa e cv. Verão em atmosfera modificada. Acta Scientiarum Agronomy, 32(2), 285-292.

Bieniasz, M., Małodobry, M., Dziedzic, E., 2012. The effect of foliar fertilization with calcium on quality of strawberry cultivars 'Luna' and 'Zanta'. Acta Horticulturae, 26(9), 457461.

Brackmann, A., Pavanello, E.P., Both, V., Janisch, D.I., Schmitt, O.J., Giménez, G., 2011. Avaliação de genótipos de morangueiro quanto à qualidade e potencial de armazenamento. Revista Ceres, 58(5), 542-547.

Cajamarca, S.M.N., Alencar, E.R., Santana, A.P., Leão, T.P., Ferreira, W.F.S., 2017. Efeito do ozônio na qualidade póscolheita de morangos produzidos em sistema orgânico. Boletim do Centro de Pesquisa de Processamento de Alimentos, 35(2), 1-12.

Castricini, A., Dias, M.S.C., Martins, R.N., Santos, L.O., 2017. Morangos produzidos no semiárido de Minas Gerais: qualidade do fruto e da polpa congelados. Brazilan Journal Food Technology, 20, 1-7.

Chen, J.X., Mao, L.C., Lu, W.J., Ying, T.J., Luo, Z.S., 2016. Transcriptome profiling of postharvest strawberry fruit in response to exogenous auxin and abscisic acid. Planta, 243(1), 183-402.

Chitarra, M.I.F., Chitarra, A.B., 2005. Pós-colheita de frutos e hortaliças: fisiologia e manuseio, segunda ed. UFLA, Lavras.

Cordenunsi, B.R., Nascimento, J.R.O., Lajolo, F.M., 2003. Physic-chemical changes related to quality of five strawberry fruit cultivars during cool-storage. Food Chemistry, 83(2), $167-173$

Cunha Junior, L.C., Jacomino, A.P., Ogassavara, F.O., Trevisan, M.J., Parisi, M.C.M., 2012. Armazenamento refrigerado de morango submetido a altas concentrações de $\mathrm{CO}_{2}$. Horticultura Brasileira, 30(4), 688-694. 
Ferreira, D.F., 2014. Sisvar: a guide for its bootstrap procedures in multiple comparisons. Ciência e Agrotecnolgia, 38(2), 109-112.

Flores Cantillano, R.F.F., Castaneda, L.M.F., Treptow, R.O., Schunemann, A.P.P., 2008. Qualidade físico-química e sensorial de cultivares de morango durante o armazenamento refrigerado. Boletim de Pesquisa e Desenvolvimento. Pelotas, Embrapa Clima Temperado, 29 p.

García, J.M., Medina, R.J., Olías, J.M., 1998. Quality of strawberries automatically packed in different plastic films. Journal of Food Science, 63(6), 1037-1041.

Giampieri, F., Tulipani, S., Alvarez-suarez, J.M., Quiles, J.L., Mezzetti, B., Battino, M., 2012. The strawberry: Composition, nutritional quality, and impact on human health. Nutrition, 28(1), 9-19.

Guimarães, A.G, Oliveira, C.M., Vieira, G., Pinto, N.A.V.D., 2014. Qualidade físicas e químicas de morango passa em diferentes embalagens. Engenharia na agricultura, 22(4), 306316.

IAL. Instituto Adolfo Lutz, 2005. Métodos físico-químicos para análise de alimentos, quarta ed. Brasília: Ministério da Saúde, Agência Nacional de Vigilância Sanitária.

Macedo, L.S., Alvarenga, M.A.R., 2005. Efeitos de lâminas de água e fertirrigação potássica sobre o crescimento, produção e qualidade do tomate em ambiente protegido. Ciência e Agrotecnologia, 29(2), 296-304.
Oliveira, J., Silva, I.G., Silva, P.P.M., Spoto, M.H.F., 2014. Atmosfera modificada e refrigeração para conservação póscolheita de camu-camu. Ciência Rural, 44(6), 1126-1133.

Oliveira, T.A., Araucha, E.M.M., Leite, R.H.L., Ferreira, R.M.A., Santos, F.K.G., 2015. Conservação pós-colheita de carambola sob refrigeração com recobrimento de biofilme de gelatina e PVC. Revista Verde, 10(4), 59-66.

Panda, A.K., Goyal, R.K, Bishnoi, C., Sharma, V.K., 2016. Variation in Quality Attributes of Strawberry Fruits under Refrigerated Storage Condition with Passive Modified Atmospheric Packaging. Advances in Life Sciences, 5(11), 4485-4489.

Santos, J.S., Oliveira, M.B.P.P., 2012. Alimentos frescos minimamente processados embalados em atmosfera modificada. Brazilian Journal of Food Technology, 15(1), 114.

Soares, A.G., Fonseca, M.J.O., Motta, L.C.C., Brito, G.F.C., Oliveira, A.H.O., Campos, R.S., 2011. Embalagens e qualidade pós-colheita de frutos de morango, in: Simpósio Brasileiro de pós-colheita de frutas, hortaliças e flores-SPC. Rio de Janeiro, Embrapa, p. 247-250.

Yamashita, F., Veiga, G.F., Benassi, M.T., Roberto, S.R., 2006. Morangos embalados com filme de Policloreto de Vinila (PVC). Semina: Ciências Agrárias, 27(3), 429-436. 